\title{
FAKTOR YANG MENENTUKAN KEPUTUSAN MEMBELI APARTEMEN
}

\author{
Yance Onggo, Agus Setiawan, R. Vivien Arifianthie, Samsu Rizal, \\ yance.onggo@yahoo.com, asetiawan@gmail.com, \\ arifianthie@yahoo.com, srizal@live.com
}

\section{Program MM Sekolah Bisnis dan Ekonomi Universitas Prasetiya Mulya}

\begin{abstract}
The development and sales of apartment in Indonesia has been significantly increased in the last decade. This research will study the factors that influencing the decision to purchase an apartment in the current market. Once we understand the attributes that influencing the decision to purchase apartment, the result can be used by the developer to design the next apartment development. This quantitative research will use online questionnaire. The data is then analyzed using SPSS software. The research indicates the availability of parking lot is the most important factor for purchasing an apartment. From factor analysis, we found that there are eight factors and the sport facility is the most important factors.
\end{abstract}

Kata Kunci - Properti, Apartemen, Keputusan Membeli, Marketing, Sales

\section{SARI PATI}

Pembangunan dan penjualan apartemen di Indonesia mengalami peningkatan yang cukup signifikan dalam dekade terakhir. Penelitian ini bertujuan untuk mengetahui alasan-alasan yang dikemukakan oleh pasar sebagai pertimbangan untuk membeli apartemen. Manfaat dari penelitian ini adalah untuk mengetahui atribut-atribut yang menjadi bahan pertimbangan dalam membeli apartemen yang kemudian bisa menjadi masukan untuk membuat perencanaan apartemen di masa mendatang. Penelitian ini menggunakan metode penelitian kuantitatif dan metode pengumpulan data melalui kuesioner online. Data diolah menggunakan perangkat lunak SPSS. Ditemukan bahwa ketersediaan lahan parkir adalah pertimbangan yg paling penting dalam keputusan membeli apartemen. Selanjutnya dari factor analysis ditemukan ada delapan factor yang mempengaruhi keputusan pembelian apartemen, dan yang terpenting adalah adanya sarana olah raga.

\section{PENDAHULUAN}

Kementerian Pekerjaan Umum dan Perumahan Rakyat (PUPR) mencatat data backlog atau selisih antara pasokan rumah dan kebutuhan tahun 2017 adalah 11,4 juta (detik.com). Indonesia saat ini sedang mengalami pertumbuhan penduduk (1,2\% per tahun atau setara dengan 3 juta jiwa per tahun) dan ekonomi yang relatif stabil (+/-5\%). Sebagai akibatnya maka pertumbuhan kota-kota besar di Indonesia pun mengalami peningkatan kemajuan yang dapat dilihat dari pembangunan infrastruktur, hunian tempat tinggal, perkantoran, pertokoan, dan bertumbuhnya fasilitas-fasilitas perkotaan lainnya.

Banyak masyarakat memiliki persepsi bahwa sangat mudah untuk mendapatkan pekerjaan di kota kota besar, sehingga semua orang terus datang ke Kota (Urbanisasi). Sehingga akibatnya pertumbuhan penduduk terus naik dari waktu ke waktu. Seiring dengan kenaikan jumlah penduduk, maka permintaan tempat tinggal juga akan meningkat, yang akan diikuti oleh kenaikan harga tempat tinggal yang sangat tinggi. Sebagai contoh di Jakarta, 
masyarakat yang tidak mampu membeli tempat tinggal di Jakarta akan mencari tempat tinggal di pinggiran Jakarta. Dengan demikian pertumbuhan daerah perkotaan Jakarta bertambah luas hingga mencapai kota kota satelit di sekitar jakarta seperti Bogor, Depok, Tangerang, dan Bekasi atau yang kita kenal dengan Megapolitan / Jabodetabek.

Seiring perjalanannya, pengembangan perumahan di beberapa kota satelit yang popular seperti Serpong, Cibubur, Sentul dan bekasi saat ini harga tanahnya sudah menjadi makin mahal untuk dijadikan rumah tapak. Salah satu indikator harga tanah yang sudah naik tinggi sehingga rumah tapak menjadi mahal dan tidak terjangkau adalah banyaknya pembangunan hunian vertikal dalam bentuk apartemen.

Tujuan penelitian ini adalah untuk mencari faktor yang menjadi bahan pertimbangan pasar untuk memutuskan akan membeli apartemen atau tidak. Manfaat penelitian ini adalah diharapkan munculnya atribut-atribut yang dilihat oleh pasar sebagai faktor dalam memutuskan untuk membeli apartemen. Atribut-atribut ini kemudian diharapkan dapat menjadi masukan dalam membuat perencanaan apartemen yang sesuai dengan pasar di Indonesia.

\section{TINJAUAN PUSTAKA \& PENGEMBANGAN HIPOTESIS}

Ketika seorang konsumen memutuskan untuk membeli sebuah produk, pada dasarnya konsumen saat itu sedang berada dalam tahapan buyer decision process. Tahapan yang dilalui oleh konsumen tersebut pertama kali diperkenalkan oleh Engel, Blackwell dan Kollat (1968) yang kemudian dijelaskan lebih lanjut oleh Philip Kotler dalam bukunya Marketing Management Millenium Edition, 2000, (1) problem recognition dimana konsumen menyadari adanya masalah atau kebutuhan (2) information search dimulai saat konsumen secara aktif melakukan pencarian informasi mengenai produk yang dapat mengatasi permasalahan yang dialami atau dengan kata lain untuk memenuhi kebutuhannya (3) evaluation of alternatives yaitu konsumen mengevaluasi berbagai alternatif/pilihan produk untuk mengetahui produk mana yang pada akhirnya akan dipilih, dimana dalam tahap ini konsumen akan melihat produk sebagai satu kesatuan dari berbagai atribut yang dapat memberikan manfaat bagi konsumen (4) dalam tahapan purchase decision konsumen akan melakukan pengambilan keputusan untuk membeli produk atau tidak setelah melakukan evaluasi terhadap beberapa alternatif/pilihan di tahap sebelumnya dimana ternyata keputusan konsumen dalam tahapan ini bisa dipengaruhi oleh orang lain yang merupakan influencer-nya (5) setelah membeli produk konsumen akan masuk ke tahap akhir yaitu postpurchase behavior yang bisa berupa kepuasan atau ketidakpuasan terhadap produk yang dikonsumsi atau sebut saja postpurchase satisfaction, kemudian postpurchase action, sampai kemudian postpurchase use and disposal.

Tingkat involvement konsumen dalam masing-masing tahapan buyer decision process akan berbeda. Sebagai contoh, seorang konsumen bisa saja tidak melewati tahapan 1, 2 dan 3 dan langsung masuk ke tahap 4 dimana konsumen tersebut memutuskan untuk membeli sebuah produk. Atau di lain kesempatan konsumen yang sama bisa saja melewati tahap demi tahap dalam suatu periode yang cukup lama misalnya saat melakukan pencarian informasi produk apa yang bisa memenuhi kebutuhannya atau ketika konsumen melakukan evaluasi terhadap beberapa alternatif/pilihan produk. 
Perbedaan di atas dijelaskan lebih jauh oleh Sally Dibb dalam bukunya Marketing: Concepts and Strategies yang membagi perilaku konsumen dalam melakukan pembelian menjadi empat kategori yaitu (1) routine response behavior (2) limited decision making (3) extensive decision making (4) impulse buying.

Pembelian sebuah apartemen oleh konsumen termasuk dalam kategori pembelian dengan extensive decision making karena memiliki karakteristik (1) keputusan yang akan diambil melibatkan resiko yang cukup tinggi karena (2) produk yang akan dibeli memiliki harga yang tidak sedikit dan (3) relative jarang dibeli oleh konsumen, sehingga memunculkan (4) motivasi yang tinggi dari konsumen untuk melalui setiap tahapan proses buying decision, dimana pencarian informasi mengenai produk dilakukan oleh konsumen (5) dari berbagai sumber dalam (6) periode waktu yang cukup lama untuk kemudian (7) setiap informasi yang diperoleh akan diproses secara aktif oleh konsumen sebelum akhirnya berbagai alternatif/pilihan produk (8) dievaluasi berdasarkan banyak kriteria.

Untuk mengetahui lebih jauh faktor/atribut yang menjadi kriteria penilaian sekaligus mempengaruhi keputusan konsumen dalam membeli apartemen khususnya middle class apartment, penulis membuat sebuah survey yang akan dijelaskan pada bagian selanjutnya.

Merujuk pada penelitian sebelumnya yang dilakukan oleh Maoludyo F. T. dan Aprianingsih A. pada 2015 tentang faktor-faktor yang mempengaruhi intensi pembelian rumah di Depok, maka kami merancang kuisioner berdasarkan penelitian tersebut dan menambahkan beberapa pertanyaan yang lebih khusus tentang apartemen mengacu pada penelitian dari Nasar K K dan Manoj P K, 2015.

\section{Desain Kuesioner}

Bagian ini akan membahas pengukuran penelitian, variabel, dan indikatornya. Setiap Paragraf akan menjelaskan variabel dan definisinya, lalu ke isi kuesioner, beserta Indikator yang dinilai.

Demografi adalah data pribadi responden. Pada penelitian ini, data demografi yang ditanyakan meliputi; Jenis Kelamin, Umur, Lokasi tempat bekerja, harga apartemen yang diharapkan dan lokasi di mana apartemen untuk dibeli, tujuan membeli apartemen, dan media untuk mendapatkan informasi property. Pertanyaan pertanyaan ini akan menggunakan pertanyaan nominal untuk dijawab.

Untuk mengetahui faktor-faktor yang mempengaruhi konsumen, pertanyaan disusun berdasarkan dimensi dan atribut seperti Tabel 1. Pertanyaan atribut akan dijawab menggunakan 5 poin pada skala Likert dengan 1 sebagai sangat tidak penting dan 5 sangat penting.

Tabel 1: Atribut yang diteliti

\begin{tabular}{ll}
\hline \hline Dimensi & Atribut \\
\hline Produk & Status Sertifikat Lahan (HGB Murni / HPL) \\
& Potensi untuk disewakan (Yield) dan Kenaikan Harga \\
& (Capital Gain) \\
& Konsep Pengembangannya Superblok \\
& Nama Besar Pengembang
\end{tabular}




\begin{tabular}{ll} 
& Reputasi Kontraktor yang membangun \\
& Design Fasad Apartment \\
& (Modern/Klasik/Mediterania/Kolonial) \\
& Balkon di setiap unit \\
\hline Harga & Tingkat Suku Bunga KPA \\
& Besar DP (Down Payment) minimum KPA \\
& Kemudahan pembayaran Cash Bertahap ke Developer \\
\hline Lokasi & Lokasi dekat Rumah Sakit \\
& Lokasi dekat Universitas / Sekolah \\
& Lokasi dekat Sarana Rekreasi Keluarga (Water Park, \\
& Theme Park) \\
& Lokasi dekat Pusat Perbelanjaan/Shopping Center \\
\hline Promosi & Hadiah langsung Elektronik (Handphone, TV LED, AC) \\
& Hadiah Langsung Voucher Belanja \\
& Hadiah Langsung Furniture \\
& Discount Langsung / Potongan Harga \\
& Kolam Renang \\
& Fitness Center \\
& Jogging Track \\
& Taman Bermain anak \\
& Acces Card khusus Penghuni \\
Ketersediaan lahan Parkir \\
Lounge (Ruang Serba Guna)
\end{tabular}

Produk adalah sesuatu yang orang beli. Pada penelitian ini, indikator yang akan menjelaskan produk tersebut adalah Status Sertifikat Lahan (HGB Murni / HPL), Potensi untuk disewakan (Yield) dan Kenaikan Harga (Capital Gain), Konsep Pengembangannya Superblok, Nama Besar Pengembang, Reputasi Kontraktor yang membangun, Design Fasad Apartment (Modern/Klasik/Mediterania/Kolonial) serta Balkon di setiap unit

Harga adalah sesuatu yang orang tawarkan untuk mendapatkan produk yang mereka inginkan. Indikator harga pada ini Tingkat Suku Bunga KPA, Besar DP (Down Payment) minimum KPA dan Kemudahan pembayaran Cash Bertahap ke Developer

Dimensi berikutnya adalah adalah lokasi, Lokasi dekat Rumah Sakit, dekat Universitas / Sekolah, dekat dengan Sarana Rekreasi Keluarga (Water Park, Theme Park) dan Lokasi dekat Pusat Perbelanjaan / Shopping Center.

Selanjutnya adalah dimensi promosi. Promosi tersebut merupakan upaya pengembang untuk memasarkan produknya. Promosi yang berkorelasi dengan properti adalah Hadiah langsung Elektronik (Handphone, TV LED, AC), Hadiah Langsung Voucher Belanja, Hadiah Langsung Furniture dan Discount Langsung / Potongan Harga

Dimensi terakhir adalah fasilitas yang ditawarkan, meliputi Kolam Renang, Fitness Center, Jogging Track, Taman Bermain anak, Access Card khusus Penghuni, Ketersediaan lahan Parkir dan Lounge (Ruang Serba Guna) 
Filter, Untuk memastikan responden mampu dan menjawab pertanyaan dengan baik, dibuatkan pertanyaan di awal kuisioner yang menselesksi apakah responden memenuhi syarat sebagai responsden yang dibutuhkan. Dengan mengajukan pertanyaan penghasilan minimum dan apakah responsden telah memiliki apartemen atau berkeinginan membeli apartamen dalam kurun waktu 1 tahun ke depan.

\section{METODOLOGI PENELITIAN}

Penelitian ini telah dilakukan selama bulan Juli - Agustus 2017, dan kuisioner disebarkan secara acak oleh penulis kepada pemilik apartemen dan atau calon pembeli apartemen. Program SPSS akan digunakan dalam menganalisis data dan menguji hipotesis penelitian. Faktor analisis digunakan untuk mengetahui faktor terbanyak yang mempengaruhi kriteria perilaku pembelian Apartmen.

Setiap responden diminta untuk menanggapi semua atribut/variabel dalam kuesioner pada lima poin Skala Likert.

\section{Analisa Data}

Data yang masuk sejumlah 393 responden, tetapi dari setelah melalui penyaringan sesuai kriteria penelitian, maka hanya ada 201 data yang valid. Data tersebut selanjutnya diolah dan dianalisa menggunakan aplikasi SPSS.

\section{Profil Responden}

Berikut adalah profil singkat demografis dari responden yang kita dapatkan dalam penelitian ini

Tabel 2: Jenis Kelamin

\begin{tabular}{|l|r|r|} 
Apakah Jenis Kelamin Anda? & $\begin{array}{c}\text { Jumlah } \\
\text { Responden }\end{array}$ & Persentase \\
\hline Pria & 136 & $67.7 \%$ \\
\hline Wanita & 65 & $32.3 \%$ \\
\hline
\end{tabular}

Tabel 3: Umur Responden

\begin{tabular}{l|r|r|} 
Berapakah umur Anda? & $\begin{array}{c}\text { Jumlah } \\
\text { Responden }\end{array}$ & Persentase \\
\hline 30 Thn - 39 Thn & 85 & $42.3 \%$ \\
\hline 20 Thn - 29 Thn & 54 & $26.9 \%$ \\
\hline $40 \mathrm{Thn}-49 \mathrm{Thn}$ & 51 & $25.4 \%$ \\
\hline$>50 \mathrm{Thn}$ & 11 & $5.5 \%$ \\
\hline
\end{tabular}

Tabel 4: Lokasi Kerja Responden

\begin{tabular}{l|r|r|} 
Dimanakah Lokasi Anda Bekerja saat ini? & $\begin{array}{c}\text { Jumlah } \\
\text { Responden }\end{array}$ & Persentase \\
\hline Jakarta & 92 & $45.8 \%$ \\
\hline Tangerang & 77 & $38.3 \%$ \\
\hline Lain Lain & 21 & $10.4 \%$ \\
\hline Bekasi & 6 & $3.0 \%$ \\
\hline Bogor & 4 & $2.0 \%$ \\
\hline Depok & 1 & $0.5 \%$ \\
\hline
\end{tabular}

Tabel 5: Harga Apartemen Yang Diinginkan 


\begin{tabular}{l|r|r|}
$\begin{array}{l}\text { Berapa Harga Apartment yang Anda Rencanakan beli } \\
\text { dalam waktu dekat ini / } \mathbf{~ t h n ~ k e ~ d e p a n ? ~}\end{array}$ & $\begin{array}{c}\text { Jumlah } \\
\text { Responden }\end{array}$ & Persentase \\
\hline 251 Juta - 500 Juta & 95 & $47.3 \%$ \\
\hline < 250 Juta & 50 & $24.9 \%$ \\
\hline 501 Juta - 1 Milyar & 41 & $20.4 \%$ \\
\hline 1 Milyar - 2 Milyar & 13 & $6.5 \%$ \\
\hline > 2 Milyar & 2 & $1.0 \%$ \\
\hline
\end{tabular}

Tabel 6: Lokasi Apartemen Yang Diinginkan Jika Diluar Jakarta

\begin{tabular}{l|r|r|} 
Jika di Luar Jakarta, dilokasi mana Anda berminat & $\begin{array}{c}\text { Jumlah } \\
\text { membeli Apartment? }\end{array}$ & Persentase \\
\hline Tangerang & 102 & $50.7 \%$ \\
\hline Lain Lain & 48 & $23.9 \%$ \\
\hline Bekasi & 26 & $12.9 \%$ \\
\hline Bogor & 16 & $8.0 \%$ \\
\hline Depok & 9 & $4.5 \%$ \\
\hline
\end{tabular}

Tabel 7: Tujuan Pembelian Apartemen

\begin{tabular}{|l|r|r|}
\hline Apakah tujuan Anda membeli Apartment? & $\begin{array}{c}\text { Jumlah } \\
\text { Responden }\end{array}$ & Persentase \\
\hline Investasi & 149 & $74.1 \%$ \\
\hline Digunakan Sendiri & 52 & $25.9 \%$ \\
\hline
\end{tabular}

Tabel 8: Media Pilihan Untuk Mencari Informasi Apartemen

\begin{tabular}{|c|c|c|}
\hline $\begin{array}{l}\text { Untuk mecari informasi Property, Anda lebih suka } \\
\text { mencari di mana? }\end{array}$ & $\begin{array}{c}\text { Jumlah } \\
\text { Responden }\end{array}$ & Persentase \\
\hline Portal Property (Rumah123.com/Lamudi.com) & 87 & $43.3 \%$ \\
\hline Google & 87 & $43.3 \%$ \\
\hline Digital News (detik.com/kompas.com) & 12 & $6.0 \%$ \\
\hline Koran / Majalah & 10 & $5.0 \%$ \\
\hline Lain Lain & 5 & $2.5 \%$ \\
\hline
\end{tabular}

\section{Tingkat kepentingan dari atribut yang diteliti}

Analisa terhadap 25 atribut yang ditanyakan dalam survey seluruhnya memiliki nilai ratarata diatas 3 , berarti seluruh atribut ini dianggap penting oleh responden. Nilai tertinggi diperoleh oleh atribut Ketersediaan Lahan Parkir dengan nilai kepentingan rata-rata sebesar 4.73

Grafik 1: Nilai Kepentingan Atribut 
Nilai Kepentingan Atribut

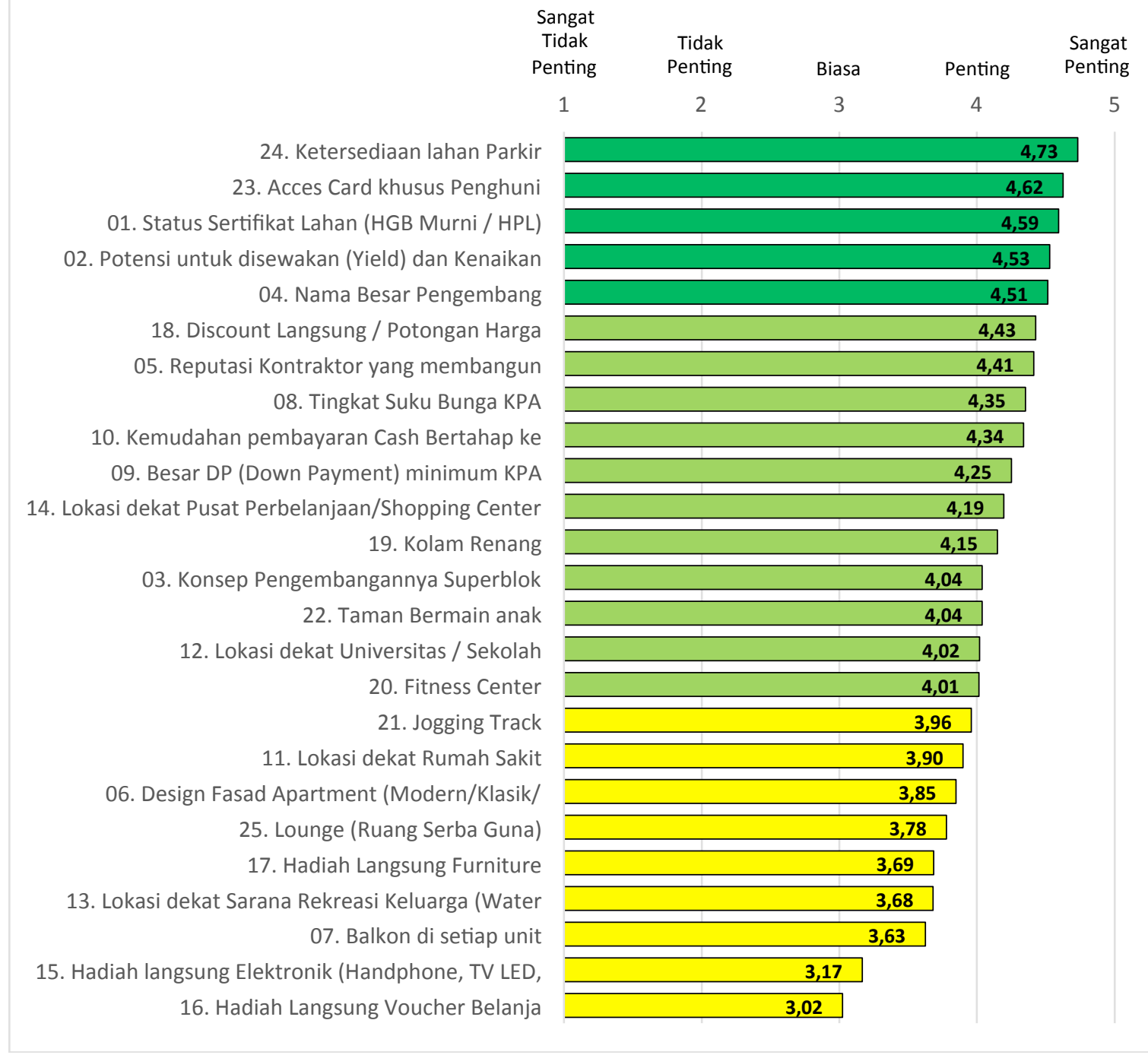

Jika ditelaah lebih lanjut dari seluruh atribut yang diteliti, empat atribut tertinggi memiliki nilai yang cukup unggul secara menyolok yaitu: (1) Ketersediaan lahan parkir (2) Access Card penghuni (3) Status lahan (4) Potensi untuk disewakan kembali. Ini bisa diartikan bahwa kenyamanan dan keamanan adalah hal yang sangat penting. Ketersediaan parkir dan access card bisa diartikan sebagai kenyamanan \& keamanan tinggal di apartemen, sementara status sertifikat lahan serta potensi disewakan kembali dan kenaikan harga bisa diartikan sebagai keamanan investasi.

\section{Analisis Faktor}

Tahap analisa berikutnya menggunakan metode factor analysis untuk mengetahui hubungan antar atribut. Dalam tes pendahuluan untuk mengukur kecukupan sampel untuk setiap variabel dalam model didapatkan skor Kaiser-Meyer-Olkin sebesar 0.728 , ini berarti jumlah sample sudah cukup untuk melakukan Factor Analysis dan membuat model secara lengkap. Hasilnya ditemukan ada tujuh faktor / dimensi, seperti pada table dibawah.

Tabel 9: Factor Analysis - Rotated Component Matrix 


\begin{tabular}{|c|c|c|c|c|c|c|c|}
\hline & $\begin{array}{l}\text { Sarana } \\
\text { Olah } \\
\text { Raga }\end{array}$ & Hadiah & $\begin{array}{l}\text { Pe- } \\
\text { ngem- } \\
\text { bang }\end{array}$ & Lokasi & $\begin{array}{l}\text { Pem- } \\
\text { biaya- } \\
\text { an }\end{array}$ & $\begin{array}{l}\text { Fasili- } \\
\text { tas }\end{array}$ & Desain \\
\hline 20. Fitness Center & 0.846 & & & & & & \\
\hline 19. Kolam Renang & 0.798 & & & & & & \\
\hline 21. Jogging Track & 0.777 & & & & & & \\
\hline 22. Taman Bermain anak & 0.568 & & & & & & \\
\hline $\begin{array}{l}\text { 15. Hadiah langsung } \\
\text { Elektronik (Handphone, } \\
\text { TV LED, AC) }\end{array}$ & & 0.877 & & & & & \\
\hline $\begin{array}{l}\text { 16. Hadiah Langsung } \\
\text { Voucher Belanja }\end{array}$ & & 0.876 & & & & & \\
\hline $\begin{array}{l}\text { 17. Hadiah Langsung } \\
\text { Furniture }\end{array}$ & & 0.704 & & & & & \\
\hline $\begin{array}{l}\text { 02. Potensi untuk disewakan } \\
\text { (Yield) dan Kenaikan } \\
\text { Harga (Capital Gain) }\end{array}$ & & & 0.801 & & & & \\
\hline $\begin{array}{l}\text { 01. Status Sertifikat Lahan } \\
\text { (HGB Murni / HPL) }\end{array}$ & & & 0.692 & & & & \\
\hline $\begin{array}{l}\text { 03. Konsep } \\
\text { Pengembangannya } \\
\text { Superblok }\end{array}$ & & & 0.666 & & & & \\
\hline $\begin{array}{l}\text { 05. Reputasi Kontraktor yang } \\
\text { membangun }\end{array}$ & & & 0.517 & & & & \\
\hline $\begin{array}{l}\text { 04. Nama Besar } \\
\text { Pengembang }\end{array}$ & & & 0.514 & & & & \\
\hline 11. Lokasi dekat Rumah Sakit & & & & 0.799 & & & \\
\hline $\begin{array}{l}\text { 12. Lokasi dekat Universitas } \\
\text { / Sekolah }\end{array}$ & & & & 0.767 & & & \\
\hline $\begin{array}{l}\text { 13. Lokasi dekat Sarana } \\
\text { Rekreasi Keluarga (Water } \\
\text { Park, Theme Park) }\end{array}$ & & & & 0.503 & & & \\
\hline 08. Tingkat Suku Bunga KPA & & & & & 0.818 & & \\
\hline $\begin{array}{l}\text { 09. Besar DP (Down } \\
\text { Payment) minimum KPA }\end{array}$ & & & & & 0.807 & & \\
\hline $\begin{array}{l}\text { 24. Ketersediaan lahan } \\
\text { Parkir }\end{array}$ & & & & & & 0.741 & \\
\hline $\begin{array}{l}\text { 23. Acces Card khusus } \\
\text { Penghuni }\end{array}$ & & & & & & 0.666 & \\
\hline 07. Balkon di setiap unit & & & & & & & 0.738 \\
\hline $\begin{array}{l}\text { 06. Design Fasad Apartment } \\
\text { (Modern /Klasik } \\
\text { /Mediterania /Kolonial) }\end{array}$ & & & & & & & 0.642 \\
\hline Eigenvalues & 5.369 & 2.349 & 1.981 & 1.938 & 1.643 & 1.365 & 1.167 \\
\hline $\begin{array}{l}\text { Percentage of variance } \\
\text { explained }\end{array}$ & 21.478 & 9.396 & 7.922 & 7.752 & 6.572 & 5.462 & 4.670 \\
\hline
\end{tabular}


Dari tujuh dimensi, factor analysis menunjukkan dimensi yang paling penting adalah dimensi sarana olahraga dengan eigenvalues sebesar 5.369 yang menjelaskan $21.47 \%$ varian yang terjadi. Secara lengkap ketujuh dimensi tersebut adalah:

(1) sarana olahraga, (2) hadiah, (3) pengembang, (4) lokasi, (5) pembiayaan, (6) fasilitas, dan

(7) desain

\section{KESIMPULAN}

Responden yang diteliti adalah yang memenuhi 2 kriteria, yaitu: memiliki penghasilan lebih dari 6 juta per bulan dan sudah memiliki apartemen atau berencana membeli apartemen dalam waktu dekat (1 tahun ke depan). Kita dapat melihat karakteristik dari responden yang diteliti adalah 69,2\% berada di umur produktif yaitu dengan rentang umur 20 - 39 tahun dengan lokasi tempat kerja $84,1 \%$ berada di Jakarta dan Tangerang, memiliki keinginan untuk berinvestasi di apartemen sebanyak 74,1\% dengan range harga <250 juta dan $251-$ 500 juta sebanyak $72,2 \%$.

Dari seluruh atribut yang diteliti, terdapat lima atribut dengan nilai rata-rata yang sangat tinggi sehingga dianggap paling penting yang mempengaruhi seseorang dalam memutuskan membeli sebuah apartemen adalah (1) ketersediaan lahan parkir, (2) adanya fasilitas keamanan berupa kartu akses, (3) kepastian status hukum dari lahan apartemen yang dijual, (4) potensi pengembangan investasi dari apartemen tersebut yaitu berupa kemudahan menyewakan kembali atau kenaikan harga pada saat dijual kembali, dan (5) nama besar pengembang. Dengan demikian penelitian ini menemukan atribut yang lebih spesifik dari penelitian sebelumnya dalam penentuan keputusan pembelian apartemen.

Dengan factor analysis, penelitian ini menemukan ada tujuh dimensi faktor yang menentukan keputusan membeli apartemen, dimana dimensi fasilitas olahraga (yang berupa kolam renang, jogging track, fitness center, taman bermain anak) adalah dimensi yang paling penting.

Hasil temuan penelitian ini (baik dimensi maupun atribut) bisa digunakan oleh pengembang apartemen untuk melakukan perencanaan bisnis ke di masa depan dengan menjadikannya sebagai masukan dalam perencanaan desain apartemen sampai ke perencanaan pemasaran, penjualan dan promosi.

\section{Keterbatasan Penelitian dan Penelitian Berikutnya}

Penelitian ini memiliki keterbatasan, salah satunya karena penelitian ini hanya bersifat kuantitatif dan survey hanya dilakukan secara online (convenience sampling). Dalam pengolahan data kami menemukan beberapa data atau jawaban responden yang aneh atau mencurigakan seperti menjawab sangat penting pada semua pertanyaan, sehingga kami menyingkirkan jawaban tersebut.

Beberapa hal dapat dilakukan untuk meningkatkan penelitian berikutnya. Penelitian bisa dilakukan di kota besar lainnya yang memiliki populasi penduduk menyerupai kota satellite di Jakarta, seperti Bandung, Surabaya, Medan, Makasar, dll. Perbedaan lokasi dan harga jual tanah di setiap area mungkin akan mempengaruhi karakteristik konsumen. Penelitian berikutnya mungkin juga difokuskan untuk mendalami secara kualitatif mengapa 
"Ketersediaan lahan parkir" muncul sebagai atribut terpenting dalam keputusan membeli apartemen.

\section{DAFTAR PUSTAKA}

Maoludyo F. T. dan Aprianingsih A. (2015), "Factors Influencing Consumer Buying Intention for Housing Unit in Depok", Journal of Business and Management, Vol. 4, No.4, 2015: 484-493

Nasar K K, \& Manoj P K (2015), "Purchase Decision for Apartments: A Closer Look Into The Major Influencing Factors", IMPACT: International Journal of Research in Applied, Natural and Social Sciences (IMPACT: IJRANSS), Vol. 3, Issue 5, May, 2015, 105-112

Mollah M. M. H., Haque I., dan Pasha S. H. A. (2009), "Factors Influencing Apartment Buying Decision: An Analysis of Company and Customer Perspective", Southeast University Journal of Business Studies, Vol. V, No.2, July-December, 2009: 109-121

Engel J. F., Kollat D. T., dan Blackwell R. D. (1968), Consumer Behavior, Holt, Rinehart, and Winston

Kotler P. (2000), Marketing Management: Millennium Edition, Prentice Hall

Dibb S., Simkin L., Pride W. M., dan Ferrell O. C. (2005), Marketing: Concepts and Strategies, Cengage Learning

Detik Finance, https://finance.detik.com/properti/3279081/kementerian-pupr-backlogperumahan-kini-tinggal-114-juta; (1 Agustus 2017) 